\title{
Erratum to: Functional expression of the human coagulation factor IX using heterologous signal peptide and propeptide sequences in mammalian cell line
}

\author{
Shohreh Khorshidi • Alireza Zomorodipour • \\ Mehrdad Behmanesh • \\ Jafar Vatandoost $\cdot$ Mettine H. A. Bos
}

Published online: 8 August 2015

(C) Springer Science+Business Media Dordrecht 2015

\section{Erratum to: Biotechnol Lett DOI 10.1007/s10529-015-1868-3}

The authors wish to correct the affiliation of the coauthor Jafar Vatandoost to: Department of Biology, Hakim Sabzevari University, Sabzevar, Iran.

The online version of the original article can be found under doi:10.1007/s10529-015-1868-3.

S. Khorshidi - M. Behmanesh

Department of Molecular Genetics, Faculty of Biological

Sciences, Tarbiat Modares University, Tehran, Iran

A. Zomorodipour $(\square)$

Department of Molecular Genetics, National Institute of Genetic Engineering and Biotechnology,

P.O. Box: 14965/161, Tehran, Iran

e-mail: zomorodi@nigeb.ac.ir

J. Vatandoost

Department of Biology, Hakim Sabzevari University,

Sabzevar, Iran

M. H. A. Bos

Department of Thrombosis and Haemostasis, Leiden

University Medical Centre, Leiden, The Netherlands 